\title{
Identification of the Volatile Compounds and Sensory Attributes of Long-Term Aging Vin Santo Wine from Malvasia di Candia Aromatic Grapes
}

\author{
Monica Laureati ${ }^{1}$, Camilla Cattaneo ${ }^{1, * \mathbb{C}}$, Fernando Tateo ${ }^{2}$ and Monica Bononi ${ }^{2}$ (D) \\ 1 Department of Food, Environmental and Nutritional Sciences (DeFENS), University of Milan, \\ 20133 Milan, Italy; monica.laureati@unimi.it \\ 2 Department of Agricultural and Environmental Sciences (Di.S.A.A), University of Milan, 20133 Milan, Italy; \\ fernando.tateo@unimi.it (F.T.); monica.bononi@unimi.it (M.B.) \\ * Correspondence: camilla.cattaneo@unimi.it; Tel.: +39-02-5031-9171
}

Received: 16 October 2020; Accepted: 23 November 2020; Published: 25 November 2020

\begin{abstract}
In an effort to offer a contribution to fill the gap of knowledge about the relationship between the sensory properties and aromatic profile of Malvasia grapes, the present work was aimed at evaluating volatile compounds, aroma, and sensory attributes of long-term aging (15 years) Vin Santo wine obtained from Malvasia di Candia aromatica grapes. In this article, the aromatic profile are studied using gas chromatography-mass spectrometry (GC-MS), gas chromatography with flame ionization detection (GC-FID), and sensory analysis by involving a panel of trained assessors to explore the sensory profile resulting after long-term aging (up to 15 years). The GC-MS and GC-FID analyses of wines allowed the identification and semi-quantification of twenty-seven volatiles belonging to 12 conventional groups of compounds. From a sensory perspective, the Vin Santo wines analyzed in this study presented a very complex sensory profile characterized by 19 sensory descriptors of which 14 related to olfactory terms. The relationship between sensory and GC-FID data deduced from three samples representing nearly three years in the past 15 years was investigated by means of Partial Least Square (PLS) modeling, showing that specific volatile compounds could predict a specific orthonasal and/or retronasal odor perceived by the trained panel of assessors, clearly differentiating the Vin Santo vintages. Identifying the main volatiles and aromas of long-term Vin Santo wine may be helpful to winemakers, since wine aging sensory properties are often associated with a prestigious image and contribute to defining wine quality.
\end{abstract}

Keywords: passito wines; sensory profiling; aroma compounds; aged Vin Santo wines

\section{Introduction}

Vin Santo is a traditional term referring to a variety of dessert wines that have been historically produced in Italy and Greece. In Italy, Vin Santo wines are commonly named Passito wines, which literally means wines produced from dried grapes [1]. The major production areas are settled, particularly, in Tuscany and in some other northern and central viticulture areas of Italy [2]. Today, Italian Vin Santo is recognized and protected by EU regulations as a Quality Wine Produced in Specific Regions (QWPSR) under the specific Protected Designation of Origin (PDO). The European legislation [3] defines "Vin Santo" as follows:

"Vin Santo", "Vino Santo", "Vinsanto" is a historical-traditional term related to some wines produced in Italian regions such as Toscana, Marche, Umbria, Emilia Romagna, Veneto, and Trentino Alto Adige. It corresponds to a particular wine typology and to the 
corresponding complex production method which implies storage and wine grapes drying in suitable and aerated places for a long aging period into traditional wooden containers.

Italian Vin Santo wines traditionally follow the same production method, although there are major differences in the must composition (grape varieties and grape drying), fermentation, and aging conditions, which lead to a great diversity of Vin Santo sensory quality [1]. Vin Santo is made by choosing the best grapes ('scelti', literally selected) of the white varieties that grow in a specific production area. A blend of non-varietal grapes (i.e., grapes not belonging to a single production area, e.g., Trebbiano) and aromatic (e.g., Malvasia) or semi-aromatic grapes (e.g., Grechetto) is made to confer to the final product the typical aromatic style. After harvesting, grapes are partially dried indoors under ambient conditions or directly on the sun for a period long enough (usually 3-4 months) to achieve a sugar concentration ranging from $26 \%$ to $48 \%$. After having separated the healthy berries from the rot and damaged ones, dried grapes are pressed, resulting in a high-sugar-containing must, which is left to settle for 3-4 days. Then, the decanted juice is fermented and matured in $50 \mathrm{~L}$ to $200 \mathrm{~L}$ traditional wooden barrels (usually chestnut, oak, or cherry) known as 'caratelli' for a period of 2-4 or even more years in the cellar or 'vinsantaia', which is a traditional room usually located in the attic of wineries, with the ventilation managed by opening the windows, thus being more subjected to seasonal temperature variations [1,4]. According to the traditional process, during maturation, the wines are subject to fluctuation in seasonal temperatures [2] which can be extremes, especially if 'vinsantaia' is chosen, and in relation to the length of the aging period and to the microbial population biodiversity involved in the fermentation [5,6]. Significant variations in the chemical and physical wine composition occur with important consequences, not always foreseeable, on perceived sensory properties [1].

The different types of Vin Santo are characterized by complex sensory profiles, which mainly arise from the blend of grapes and the winemaking process used. In general, this winemaking process provides demi-sec style (10-50 g/L of residual sugar content) or slightly sweet or sweet style wines (up to $100 \mathrm{~g} / \mathrm{L}$ of residual sugar content) characterized by pale to dark amber color and by raisin, nutty, honey and hay notes, with generally high alcohol content (14\% and above) $[7,8]$. Moreover, Vin Santo body can vary from low structure to full-body depending on the net extract content [1].

To the best of our knowledge, there are no published data on Colli Piacentini DOC (Denominazione di Origine Controllata) Vin Santo, and few studies have been carried out on Malvasia grapes considering its sensory properties and relating them to the aromatic profile. The wines evaluated in the present study were produced by Malvasia di Candia aromatica, a grapevine (Vitis vinifera L.) cultivar (cv.) that produces aromatic white grapes, cultivated in Emilia Romagna in the area of Reggio Emilia, Parma, and Piacenza, while in Lombardy it is cultivated in the area of Oltrepò Pavese. This cv. is used to produce semi-sparkling, semi-dry or sweet wines, and more recently, dry or passito wines [9].

Although Vin Santo is a niche product, its production has increased over the years, following the general increase in demand for sweet wines, corresponding to $+20 \%[1,10]$. Due to the great influence that winemaking process and grape variety may have on the quality properties of Vin Santo wine, and due to the low standardization of Vin Santo winemaking, so far, there have been few scientific studies that have focused on long-term Vin Santo aging [1,11].

Wine aging starts at the end of fermentation and continues after bottling until consumption. Its duration is variable depending on the wine's origin, type, and quality. Many changes occur in wine composition during this period, including the development of color, aroma, and flavor [12]. The speed of such a transformation is not the same for all wines as it depends on their initial composition and cellar conditions [13]. Chemical reactions of the phenolic fraction, resulting in the formation of oligomeric and polymeric derivatives, are the major contributors to wine aging [12,13]. With aging, the color gradually changes from cherry-red to deep red, and then brick-red for red wines; while for white wines, color changes from pale yellow to amber, deep-yellow-orange [12]. Concerning odor, development of wine's aromatic profile during aging usually includes the loss of fermentative aromas, a variable attenuation of fresh fruity note, retention of varietal aromas, and an evolution towards more complex and subtle aromas, resulting in a homogeneous, harmonious flavor [14]. During aging, 
the wine's aromatic profile develops from primary and secondary aromas or metabolites, under the influence of outside parameters, including aging in wooden barrels and oxygen levels during bottle storage [15-17]. Oral sensations, such as astringency and body, are also subject to modification during aging, as tannins undergo transformations that produce a reduction in astringency perception [12]. Although mainly associated with red wines, aging also applies to white wines. Recently, the effect of aging on white wines has been evaluated in a number of studies [18-28], but little attention has been given to Vin Santo wine. Domizio et al. [2] correlated the complex phenomena during maturation with the chemical and sensory characteristics of Vin Santo made under different experimental conditions (i.e., different inoculum of starter strains), although the data reported are referred to a relatively short aging period of 18 months. Moreover, very few papers have been published that deals with identifying the volatile compounds and sensory properties of long-term aging.

In this regard, the present study was carried out to make a contribution to the knowledge of the resulting sensory properties that characterize Vin Santo long-term aging (up to 15 years) by analyzing its aromatic profile through GC-MS, GC-FID, and sensory characteristics involving a panel of trained assessors. To carry out a preliminary study on the sensory effect of aging of Vin Santo produced by Malvasia di Candia aromatic grapes, the samples available at the producer and derived from 3 vintages $(2004,2005,2006)$ were examined. These samples represent today the average result of the evolution of the sensory properties correlated to analytical data detected after 15 years of aging. Identifying the main volatiles and sensory properties of long-term Vin Santo wine may be helpful to winemakers, since the wine aging bouquet is often associated with a prestigious image, linked to tradition and refined winemaking, and clearly contributes to defining wine quality [14].

\section{Materials and Methods}

\subsection{Chemicals and Reagents}

Ethanol ( $\geq 99.8 \%$ ) and water for high-performance liquid chromatography (HPLC) was purchased from Carlo Erba Reagents (Milan, Italy), while ethyl octanoate ( $\geq 98 \%$ ) and sodium sulfate anhydrous ( $\geq 99.0 \%$ ) were purchased from Sigma Aldrich (Milan, Italy).

\subsection{Standard Solutions}

For semi-quantitative analysis, a stock solution of ethyl octanoate was prepared by dissolving the compound in $10 \%(v / v)$ ethanol solution. Working standard solutions were prepared to cover two range of concentration: $0.2-2.0-20.0-40.0-100.0-200.0 \mu \mathrm{g} \mathrm{L}^{-1}\left(\mathrm{R}^{2}=0.994\right)$ and $200.0-400.0-1000.0-2000.0 \mu \mathrm{g} \mathrm{L}^{-1}$ $\left(R^{2}=0.998\right)$. These two calibration curves were used for estimating the order of magnitude of the 27 compounds semi-quantified by GC-FID and identified by GC/MS (minimum percentage of threshold reliability $95 \%$ by National Institute of Standards and Technology (NIST) 147 library spectra database and $97 \%$ by DIFCA-UniMi 2017 (today "Di.S.A.A. library") flavor spectra specific database; data expressed as $\mu \mathrm{g} \mathrm{L}^{-1}$ of ethyl octanoate). "Di.S.A.A. library" was made initially with standard certified compounds and also with some commercial compounds. Over the years, all the commercial compounds were confirmed by standard certified compounds.

\subsection{Wine Samples}

The wine analyzed in the present study was a Colli Piacentini DOC Vinsanto Albarola Val di Nure produced and bottled by a wine company from the area of Piacenza (Italy). Colli Piacentini DOC Vinsanto di Albarola is a Vin Santo exclusively made from Malvasia di Candia aromatic grapes. Three vintages (2004, 2005, and 2006) were evaluated in duplicate for GC-MS, GC-FID, and sensory parameters in spring 2019. All the samples considered were at about $10 \%(v / v)$ alcoholic degree. 


\subsection{Sample Preparation for GC-FID and GC-MS Analysis}

To $20 \mathrm{~mL}$ of each wine were added $2 \mathrm{~mL}$ of ethyl alcohol and accurately shacked. Small quantities of sodium sulfate anhydrous were added gradually, and were mixed with care. The resulting residue alcoholic fraction was isolated from the crystallized sodium sulfate by centrifugation at $5000 \mathrm{rpm}$, and $2 \mu \mathrm{L}$ of the supernatant were injected directly in GC-MS and in GC-FID.

Ethyl alcohol was added to allow easier recovery of the liquid fraction containing the volatile compounds. A semi-quantitative analysis considered the resulting dilution of the alcoholic fraction of the matrix, and the total water absorbed from the system by sodium sulfate anhydrous.

\subsection{GC-MS Analysis}

The GC-MS analyses were carried out using a Shimadzu 2010 gas chromatograph coupled to a Shimadzu QP-2010 MSD quadrupole mass spectrometer (Shimadzu, Milan, Italy). A Restek Rxi-5ms $30 \mathrm{~m} \times 0.25 \mathrm{~mm}, 0.25 \mu \mathrm{m}$ film thickness capillary silica column (Restek, Milan, Italy) was used for the volatile compounds' separation. The operating conditions were: Helium flow $1.0 \mathrm{~mL} \mathrm{~min}^{-1}$ and oven temperature $40^{\circ} \mathrm{C}$ for $1 \mathrm{~min}$, increased to $60^{\circ} \mathrm{C}$ at a rate of $2{ }^{\circ} \mathrm{C} \mathrm{min}-1$, increased to $240{ }^{\circ} \mathrm{C}$ at a rate of $3{ }^{\circ} \mathrm{C} \mathrm{min}^{-1}$, and $30 \mathrm{~min}$ hold; injection was in split mode (1:5), and the injector and detector temperatures were set at $220^{\circ} \mathrm{C}$ and $240{ }^{\circ} \mathrm{C}$, respectively. The MS ran in electron impact (EI) mode was at $70 \mathrm{eV}$ electron energy, and the temperature of the ion source was $200{ }^{\circ} \mathrm{C}$. Mass spectra were acquired over the mass range 40-300 a.m.u. (atomic mass unit). Volatile compounds were identified by matching their mass spectra with the reference mass spectra of an in-house databank "Di.S.A.A. library" (threshold of probability $>97 \%$ ) and that of NIST 147 library (threshold of probability $>95 \%$ ). The list of the volatile compounds identified is reported in Table 1.

Table 1. Volatile compounds identified by GC-MS.

\begin{tabular}{c}
\hline Compound \\
ethyl acetate \\
ethyl propionate \\
2,4,5-trimethyl-1,3-dioxolane \\
amyl alcohol + isoamyl alcohol \\
ethyl isobutyrate \\
2,3 butanediol \\
ethyl butyrate \\
ethyl 2-methyl butyrate \\
ethyl isovalerate \\
1-hexanol \\
isoamyl acetate \\
limetol \\
ethyl hexanoate \\
ocimene quintoxide \\
linalool oxide \\
nonanal \\
phenethyl alcohol \\
diethyl succinate \\
alpha terpineol \\
octanoic acid \\
ethyl octanoate \\
$\beta$-phenethyl acetate \\
$\alpha$-ionone \\
butyl octanoate \\
ethyl decanoate \\
isoamyl octanoate \\
ethyl dodecanoate \\
\hline
\end{tabular}




\subsection{GC-FID Analysis}

GC-FID analyses were carried out with a Shimadzu 2010 Plus gas chromatograph (Shimadzu, Milan, Italy). Hydrogen was used as the carrier gas at a flow rate of $1.5 \mathrm{~mL} \mathrm{~min}{ }^{-1}$. All the compounds were quantified using an Equity- 5 capillary column poly (5\% diphenyl/95\% dimethyl siloxane) $60 \mathrm{~m} \times 0.25 \mathrm{~mm}, 0.25 \mu \mathrm{m}$ i.d. film thickness) (Supelco, Milan, Italy). The oven temperature program was $40{ }^{\circ} \mathrm{C}$ for $1 \mathrm{~min}$, increased to $60^{\circ} \mathrm{C}$ at a rate of $2{ }^{\circ} \mathrm{C} \mathrm{min}-1$, increased to $240{ }^{\circ} \mathrm{C}$ at a rate of $3{ }^{\circ} \mathrm{C}$ $\mathrm{min}^{-1}$, and $30 \mathrm{~min}$ hold 240 . The injector temperature was $220^{\circ} \mathrm{C}$, and the split injector mode (1:5) was used. The detector temperature (FID) was $240{ }^{\circ} \mathrm{C}$.

The capillary columns adopted for GC-MS and for GC-FID analyses, both with low polarity, are absolutely equivalent in resolution sequencing because they are characterized by the same stationary phase $5 \%$ poly dimethyl siloxane (i.d. $0.25 \mathrm{~mm}$, film thickness $0.25 \mu \mathrm{m}$ ). Therefore, the correct identification of peaks is guaranteed.

\subsection{Sensory Analysis}

The sensory profiling method was applied to identify and quantify wines' sensory properties [29]. Nine subjects (five women and four men aged between 20 and 60) were selected from a pool of expert panelists [30]. The method consisted of an initial training phase to acquire familiarity with the product and the methodology, followed by a second phase focused on wines evaluation. Subjects were informed about the aim of the study (i.e., analyzing the sensory profile of Vin Santo wine) and were involved in six $1 \mathrm{~h}$ common sessions and four sessions in individual sensory booths. During the training phase, commercial Vin Santo wines covering a wide range of variability were selected and presented to the assessors to stimulate the generation of descriptors. As training progressed, descriptive terms were defined through a panel discussion, and relevant reference standards, corresponding to the maximum intensity of the rating scale, were developed (Table 2). No further reference standards for intermediate scale intensity were used.

Table 2. Sensory vocabulary used by the trained panel of judges to describe the sensory profile of Vin Santo wines during aging with definition and reference standards for each term elicited. If not differently reported, the standard reference refers to the maximum intensity of the scale.

\begin{tabular}{|c|c|c|}
\hline Sensory Descriptor & Definition & Reference Standard \\
\hline \multicolumn{3}{|c|}{ APPEARANCE } \\
\hline Amber color & $\begin{array}{l}\text { Characteristic perceived through the sense of } \\
\text { sight referring to the orange-yellow color } \\
\text { reminiscent of amber material }\end{array}$ & Rum Puerto Oscuro (CFL S.p.A., Finale Emilia, Italy) \\
\hline \multicolumn{3}{|c|}{ ODOR (Orthonasal perception) } \\
\hline Solvent & $\begin{array}{l}\text { Characteristic perceived through the sense of } \\
\text { smell and reminiscent of the nails polish remover }\end{array}$ & $\begin{array}{c}2 \mathrm{~mL} \text { of acetone in } 300 \mathrm{~mL} \text { of Tavernello white table } \\
\text { wine (Caviro S.p.A., Faenza, Italy) }\end{array}$ \\
\hline Honey & $\begin{array}{l}\text { Characteristic perceived through the sense of } \\
\text { smell and reminiscent of chestnut honey }\end{array}$ & $\begin{array}{l}\text { Infusion }\left(24 \mathrm{~h}, 5^{\circ} \mathrm{C}\right) \text { of } 50 \mathrm{~g} \text { of chestnut honey } \\
\text { (Apicoltori riuniti Abello, Soc. Coop. Agricola a.r.l, } \\
\text { Asti, Italy) in } 300 \mathrm{~mL} \text { of Tavernello white table wine } \\
\text { (Caviro S.p.A., Faenza, Italy) }\end{array}$ \\
\hline Caramel & $\begin{array}{l}\text { Characteristic perceived through the sense of } \\
\text { smell and reminiscent of caramel (burnt sugar) }\end{array}$ & $\begin{array}{l}2 \mathrm{~mL} \text { of caramel aroma (Funcakes Caramel Pasta } \\
\text { aromatizzante, Newcakes, NL) in } 300 \mathrm{~mL} \text { white wine } \\
\text { (Caviro S.p.A., Faenza, Italy) }\end{array}$ \\
\hline Rum & $\begin{array}{l}\text { Characteristic perceived through the sense of } \\
\text { smell and reminiscent of alcoholic spirits (rum) }\end{array}$ & Rum Puerto Oscuro (CFL S.p.A., Finale Emilia, Italy) \\
\hline Dried fruit (figs) & $\begin{array}{l}\text { Characteristic perceived through the sense of } \\
\text { smell and reminiscent of dried fruits, } \\
\text { especially dried figs }\end{array}$ & $\begin{array}{c}\text { Infusion }\left(24 \mathrm{~h}, 5^{\circ} \mathrm{C}\right) \text { of } 150 \mathrm{~g} \text { of organic dried figs } \\
\text { (EcorNaturaSì S.p.A, Verona, Italy) in } 300 \mathrm{~mL} \text { of } \\
\text { Tavernello white table wine (Caviro S.p.A., } \\
\text { Finale Emilia, Italy) }\end{array}$ \\
\hline Baked fruit (apple) & $\begin{array}{c}\text { Characteristic perceived through the sense of } \\
\text { smell and reminiscent of baked fruits, } \\
\text { especially apple }\end{array}$ & $\begin{array}{l}\text { Infusion }\left(24 \mathrm{~h}, 5^{\circ} \mathrm{C}\right) \text { of } 40 \mathrm{~g} \text { apple puree (La mousse, } \\
\text { Chini Srl, Trento, Italy) in } 300 \mathrm{~mL} \text { of Tavernello white } \\
\text { table wine (Caviro S.p.A., Faenza, Italy) }\end{array}$ \\
\hline
\end{tabular}


Table 2. Cont.

\begin{tabular}{|c|c|c|}
\hline Sensory Descriptor & Definition & Reference Standard \\
\hline Nutty & $\begin{array}{l}\text { Characteristic odor of nuts (walnuts and } \\
\text { almonds) perceived through the sense of smell }\end{array}$ & $\begin{array}{l}\text { Infusion }\left(24 \mathrm{~h}, 5^{\circ} \mathrm{C}\right) \text { of } 45 \mathrm{~g} \text { of organic walnuts } \\
\text { (Mezze noci sgusciate, Rapunzel Naturkost } \mathrm{GmbH} \text {, } \\
\text { Legau, Germany) and } 45 \mathrm{~g} \text { of toasted organic } \\
\text { almonds (Mandorle sgusciate Carrefour, GS S.p.A., } \\
\text { Milano, Italy) in } 300 \mathrm{~mL} \text { of Tavernello white table } \\
\text { wine (Caviro S.p.A., Faenza, Italy) }\end{array}$ \\
\hline \multicolumn{3}{|c|}{ TASTE } \\
\hline Sweet & $\begin{array}{l}\text { Basic taste elicited by sugars (e.g., table sugar) } \\
\text { and perceived in the oral cavity }\end{array}$ & $\begin{array}{c}130 \mathrm{~g} \text { of fructose in } 500 \mathrm{~mL} \text { of Tavernello white table } \\
\text { wine (Caviro S.p.A., Faenza, Italy) }\end{array}$ \\
\hline Sour & $\begin{array}{l}\text { Basic taste elicited by sour compounds and } \\
\text { perceived in the oral cavity }\end{array}$ & $\begin{array}{c}0.20 \mathrm{~g} \text { of tartaric acid in } 300 \mathrm{~mL} \text { of Tavernello white } \\
\text { table wine (Caviro S.p.A., Faenza, Italy) }\end{array}$ \\
\hline \multicolumn{3}{|c|}{ FLAVOUR (retronasal odor perception) } \\
\hline Solvent & $\begin{array}{c}\text { Characteristic odor perceived through the senses } \\
\text { of smell, taste, and touch perceived during } \\
\text { swallowing and reminiscent of the nails } \\
\text { polish remover }\end{array}$ & $\begin{array}{c}2 \mathrm{~mL} \text { of acetone in } 300 \mathrm{~mL} \text { of Tavernello white table } \\
\text { wine (Caviro S.p.A., Faenza, Italy) }\end{array}$ \\
\hline Honey & $\begin{array}{l}\text { Characteristic odor perceived through the senses } \\
\text { of smell, taste, and touch perceived during } \\
\text { swallowing and reminiscent of chestnut honey }\end{array}$ & $\begin{array}{l}\text { Infusion }\left(24 \mathrm{~h}, 5^{\circ} \mathrm{C}\right) \text { of } 50 \mathrm{~g} \text { of chestnut honey } \\
\text { (Apicoltori riuniti Abello, Soc. Coop. Agricola a.r.l, } \\
\text { Asti, Italy) in } 300 \mathrm{~mL} \text { of Tavernello white table wine } \\
\text { (Caviro S.p.A., Faenza, Italy) }\end{array}$ \\
\hline Caramel & $\begin{array}{c}\text { Characteristic odor perceived through the senses } \\
\text { of smell, taste, and touch perceived during } \\
\text { swallowing and reminiscent of caramel } \\
\text { (burnt sugar) }\end{array}$ & $\begin{array}{l}2 \mathrm{~mL} \text { of caramel aroma (Funcakes Caramel Pasta } \\
\text { aromatizzante, Newcakes, NL) in } 300 \mathrm{~mL} \text { white wine } \\
\text { (Caviro S.p.A., Faenza, Italy) }\end{array}$ \\
\hline Rum & $\begin{array}{c}\text { Characteristic odor perceived through the senses } \\
\text { of smell, taste, and touch perceived during } \\
\text { swallowing and reminiscent of alcoholic } \\
\text { spirits (rum) }\end{array}$ & Rum Puerto Oscuro (CFL S.p.A., Finale Emilia, Italy) \\
\hline Dried fruit (Figs) & $\begin{array}{c}\text { Characteristic odor perceived through the senses } \\
\text { of smell, taste, and touch perceived during } \\
\text { swallowing and reminiscent of dried fruits, } \\
\text { especially dried figs }\end{array}$ & $\begin{array}{c}\text { Infusion }\left(24 \mathrm{~h}, 5^{\circ} \mathrm{C}\right) \text { of } 150 \mathrm{~g} \text { of organic dried figs } \\
\text { (EcorNaturaSì S.p.A, Verona, Italy) in } 300 \mathrm{~mL} \text { of } \\
\text { Tavernello white table wine (Caviro S.p.A., } \\
\text { Faenza, Italy) }\end{array}$ \\
\hline Baked fruit (apple) & $\begin{array}{c}\text { Characteristic odor perceived through the senses } \\
\text { of smell, taste, and touch perceived during } \\
\text { swallowing and reminiscent of baked fruits, } \\
\text { especially apple }\end{array}$ & $\begin{array}{c}\text { Infusion }\left(24 \mathrm{~h}, 5^{\circ} \mathrm{C}\right) \text { of } 40 \mathrm{~g} \text { of apple puree (La } \\
\text { mousse, Chini Srl, Trento, Italy) in } 300 \mathrm{~mL} \text { of } \\
\text { Tavernello white table wine (Caviro S.p.A., } \\
\text { Faenza, Italy) }\end{array}$ \\
\hline Nutty & $\begin{array}{l}\text { Characteristic odor of nuts (walnuts and } \\
\text { almonds) perceived through the sense of smell, } \\
\text { taste, and touch during swallowing }\end{array}$ & $\begin{array}{l}\text { Infusion }\left(24 \mathrm{~h}, 5^{\circ} \mathrm{C}\right) \text { of } 45 \mathrm{~g} \text { of organic walnuts } \\
\text { (Mezze noci sgusciate, Rapunzel Naturkost } \mathrm{GmbH} \text {, } \\
\text { Legau, Germany) and } 45 \mathrm{~g} \text { of toasted organic } \\
\text { almonds (Mandorle sgusciate Carrefour, GS S.p.A., } \\
\text { Milano, Italy) in } 300 \mathrm{~mL} \text { of Tavernello white table } \\
\text { wine (Caviro S.p.A., Faenza, Italy) }\end{array}$ \\
\hline \multicolumn{3}{|c|}{ MOUTHFEEL SENSATIONS } \\
\hline Body & $\begin{array}{l}\text { Characteristic perceived in the oral cavity, due to } \\
\text { the friction among the molecules in a liquid, that } \\
\text { gives to it a limited fluidity and mobility }\end{array}$ & $\begin{array}{c}30 \mathrm{~mL} \text { of glycerol in } 300 \mathrm{~mL} \text { of Tavernello white table } \\
\text { wine (Caviro S.p.A., Faenza, Italy) }\end{array}$ \\
\hline Alcohol & $\begin{array}{l}\text { Characteristic heat/burning sensation perceived } \\
\text { in the oral cavity }\end{array}$ & $\begin{array}{l}45 \mathrm{~mL} \text { of } 95 \% \text { ethyl alcohol (Alcol Buongusto, } \\
\text { Carrefour, Milano, Italy) in } 300 \mathrm{~mL} \text { of Tavernello } \\
\text { white table wine (Caviro S.p.A., Faenza, Italy) }\end{array}$ \\
\hline
\end{tabular}

After the training phase, judges evaluated the three Vin Santo wines in two replicates on different days. Judges were instructed to drink and swallow each sample and rate the intensity of each attribute using a scale ranging from the minimum intensity of the sensation (score $=1$ ) and maximum intensity of the sensation (score $=9$, represented by the reference standards see Table 2). The training and evaluation sessions were performed, respectively, in the room for collective discussions and in individual sensory booths at the sensory laboratory of the Department of Food, Environmental and Nutritional Sciences (DeFENS, Università degli Studi di Milano) designed in accordance with ISO guidelines [31].

Data acquisition was done using Fizz v2.31 software (Biosystèmes, Couternon, France). Assessors were asked not to smoke, eat or drink anything, except water, at least one hour before the tasting sessions. For both the training and evaluation sessions, for each sample, judges received a $20 \mathrm{~mL}$ sample served in transparent ISO glasses [32] coded with a 3-digit number and covered with a Petri 
dish to avoid the escape of volatile components. Participants were provided with mineral water and unsalted crackers to clean their mouth between tastings. Wines were served at room temperature, which was set at $20^{\circ} \mathrm{C}$. Presentation orders were systematically varied over assessors and replicated to balance the effects of serving order and carryover [33].

\subsection{Data Analysis}

Sensory data were analyzed by means of 3-way ANOVA considering Wines (vintages 2004, 2005, 2006), judges (9 assessors), replicates (rep 1, rep 2), and their 2-way interactions as factors [29].

When the ANOVAs showed a significant effect $(p<0.05)$ for the factor Wines, the Least Significant Difference (LSD) was applied as a multiple comparison test.

The relationship between the sensory attributes (odors and flavors) and the GC-FID data was studied by means of the Partial Least Square (PLS) regression [34]. PLS procedure models both the $X$ - and $Y$ - matrices simultaneously to find the variables in $X$ that will best predict the variables in Y. These PLS components are similar to principal components from principal component analysis (PCA), but will be referred to as factors or latent variables or latent structures. In PLS models, Scores and Loadings express how the samples and variables are projected along with the model factors. In this experiment, sensory attributes related to orthonasal (odor) and retronasal (flavor) perception, averaged across judges, were used as Y matrix, and GC-FID data were set as X matrix. Autoscaling was performed on the data prior to any modeling. This pre-processing technique is required when variables showing different variation ranges need to be compared. It gives all variables the same chance to influence the estimation of the components. Cross-validation was chosen as the validation method. A preliminary PLS model was run considering all variables (all volatile compounds, as well as all orthonasal and retronasal sensory descriptors). A correlation loadings plot was used to find variables with less than $50 \%$ explained variance, which were left out of the model [35]. This resulted only in the omission of one volatile compound, i.e., ocimene. Variable importance for the projection (VIP) was calculated. VIP values make it possible to assess the importance of the variables for prediction in a model [36]. According to Tenenhaus et al. [36], the variables are regarded important for the prediction if VIP scores are higher than 0.8 .

Data were treated using SAS/STAT statistical software package version 9.1.3. (SAS Institute Inc., Cary, NC, USA) and XLSTAT (version 2019.2.2, Addinsoft, Boston, MA, USA).

\section{Results and Discussion}

\subsection{GC-MS and GC-FID Analysis}

All analyses were performed in duplicate, and the results of GC-FID analysis are reported in Table 3 expressed as $\mu \mathrm{g} \mathrm{L}^{-1}$ of ethyl octanoate (mean values). The GC-MS analysis of wines identified twenty-seven compounds belonging to 12 groups of volatile compounds. The volatile compounds responsible for the aroma were identified by GC-MS and by comparison with GC-FID on alcoholic extracts produced from wines.

In this work, we have identified three monoterpenes, three alcohols, one $\mathrm{C}_{6}$-compounds, ten ethyl esters, one volatile fatty acid, two acetates, and seven other compounds (i.e., aldehydes, heterocycle compounds, other esters, etc.). Many of these volatile compounds, which derive from grapes cultivar, yeast strain fermentation, and vinification process, are commonly found in wines. The aromatic profile of Malvasia di Candia aromatica cultivar has been previously studied in relation to cultivation techniques, terroir, as well as to winemaking techniques [37]. Masino et al., [38] studied various accessions of Malvasia di Candia aromatica collected in the area around Reggio Emilia grapes. Terpenoid profile was particularly rich and varied, being recognized as compounds responsible for the typical varietal aroma $[37,39,40]$. The total concentration of free monoterpenes, generally, allows the distinction between aromatic and non-aromatic grapevine varieties [41]. 
In agreement with previous research $[9,42,43]$, in the present study, we identified some terpenic alcohols and derivatives, such as alpha terpineol, limetol, and linalool oxide. The free forms of monoterpenes are normally degraded both during drying, maturation, and alcoholic fermentation thanks to the action of yeast. The concentration of this fraction is further reduced during wine-aging, through a chemical transformation that leads to the formation of other volatile compounds [43]. Higher alcohols and esters, produced during alcoholic fermentation, play an important role in the flavor of wines, depending on the type of compound and concentration [43]. Amyl and isoamyl alcohols, are reported to increase regularly during the winemaking process [43], while phenethyl alcohol derives from both varietal characteristic and fermentative process [44]. Moreover, the $\mathrm{C}_{6}$-alcohol has a pre-fermentative origin, but could also be involved in yeast metabolism [44]. The volatile fatty acids and their ethyl esters are fermentation compounds that deserve special attention for their sensory characteristics, related to both wine's pleasant note and peculiarity [43,45-47].

Table 3. Volatile compounds composition in the three vintages. Data are expressed as $\mu \mathrm{g} \mathrm{L}^{-1}$ of ethyl octanoate (SD = standard deviation).

\begin{tabular}{|c|c|c|c|c|c|c|}
\hline \multirow[t]{3}{*}{ Compound } & \multicolumn{6}{|c|}{ Vintage } \\
\hline & \multicolumn{2}{|l|}{2004} & \multicolumn{2}{|l|}{2005} & \multicolumn{2}{|l|}{2006} \\
\hline & Mean & SD & Mean & SD & Mean & SD \\
\hline \multicolumn{7}{|l|}{ Terpenoids } \\
\hline Alpha terpineol & 26.53 & 0.14 & 7.72 & 0.20 & 29.1 & 1.63 \\
\hline Limetol & 52.97 & 0.82 & 64 & 0.30 & 174.27 & 85.59 \\
\hline Linalool oxide & 13.78 & 0.04 & 11.34 & 0.07 & 18.81 & 3.72 \\
\hline Sum & 93.28 & & 83.06 & & 222.18 & \\
\hline \multicolumn{7}{|l|}{ Alcohols } \\
\hline Amyl alcohol + isoamyl alcohol & 323.37 & 5.78 & 279.61 & 1.53 & 366.64 & 30.21 \\
\hline 2,3-butanediol & 18.56 & 0.06 & 2.34 & 0.08 & 13.72 & 3.52 \\
\hline Sum & 341.93 & & 281.95 & & 380.36 & \\
\hline \multicolumn{7}{|l|}{ Aromatic alcohols } \\
\hline \multicolumn{7}{|l|}{ C6-compounds } \\
\hline 1-hexanol & 13.73 & 0.30 & 12.45 & 0.16 & 24.09 & 7.27 \\
\hline \multicolumn{7}{|l|}{ Volatile fatty acids } \\
\hline \multicolumn{7}{|l|}{ Ethyl esters } \\
\hline Ethyl acetate & 29.55 & 0.10 & 11.67 & 0.18 & 42.4 & 8.78 \\
\hline Ethyl butyrate & 7.57 & 0.07 & 7.72 & 0.06 & 9.7 & 1.34 \\
\hline Ethyl decanoate & 18.93 & 0.08 & 203.87 & 0.44 & 401.81 & 270.54 \\
\hline Ethyl dodecanoate & 4.6 & 0.03 & 8.41 & 0.28 & 10.71 & 4.70 \\
\hline Ethyl hexanoate & 112.12 & 2.60 & 169.6 & 0.54 & 291.94 & 127.39 \\
\hline Ethyl isobutyrate & 7.8 & 0.31 & 35.23 & 0.04 & 18.19 & 7.25 \\
\hline Ethyl isovalerate & 6.47 & 0.03 & 37.15 & 0.14 & 15.48 & 6.49 \\
\hline Ethyl 2-methyl butyrate & 4.4 & 0.11 & 14.27 & 0.07 & 9.18 & 3.45 \\
\hline Ethyl octanoate & 263.29 & 1.30 & 1350.81 & 7.69 & 1560.02 & 915.96 \\
\hline Ethyl propionate & 16.38 & 0.06 & 19.91 & 0.08 & 15.38 & 0.78 \\
\hline Sum & 471.11 & & 1858.64 & & 2374.81 & \\
\hline \multicolumn{7}{|l|}{ Other esters } \\
\hline Butyl octanoate & 11.09 & 0.10 & 17.73 & 0.31 & 6.53 & 3.34 \\
\hline Diethyl succinate & 326.06 & 1.40 & 218.37 & 0.04 & 411.1 & 59.76 \\
\hline Isoamyl octanoate & 0.63 & 0.01 & 1.03 & 0.08 & 0.58 & 0.08 \\
\hline Sum & 337.78 & & 237.13 & & 418.21 & \\
\hline \multicolumn{7}{|l|}{ Acetates } \\
\hline Beta-phenethyl acetate & 10.21 & 0.24 & 8.67 & 0.11 & 18.81 & 5.94 \\
\hline Isoamyl acetate & 36.06 & 0.21 & 34.78 & 0.04 & 59.05 & 16.05 \\
\hline Sum & 46.27 & & 43.45 & & 77.86 & \\
\hline \multicolumn{7}{|l|}{ Aldehydes } \\
\hline Nonanal & 4.21 & 0.11 & 4.30 & 0.13 & 8.40 & 3.10 \\
\hline \multicolumn{7}{|l|}{ Chetons } \\
\hline Alpha-ionone & 0.41 & 0.06 & 2.21 & 0.03 & 5.69 & 3.69 \\
\hline \multicolumn{7}{|l|}{ Others } \\
\hline 2,4,5-trimethyl-1,3-dioxolane & 71.28 & 0.99 & 37.74 & 0.72 & 81.98 & 7.35 \\
\hline Ocimene quintoxide & 6.13 & 0.17 & 4.45 & 0.11 & 9.14 & 2.16 \\
\hline
\end{tabular}




\subsection{Sensory Analysis}

Nineteen sensory descriptors covering appearance (amber color), odor (solvent, honey, caramel, rum, dried figs, baked apple, nutty), taste (sweet and sour), flavor (solvent, honey, caramel, rum, dried figs, baked apple, nutty) and mouthfeel (body, alcohol) were defined.

Mean intensity ratings of Vin Santo wines are reported in Table 4. ANOVA results showed that all descriptors, except nutty flavor, discriminated significantly against the wines in the three vintages.

Table 4. Influence of vintage (expressed by F-values) on mean values of each sensory descriptor. Superscripts by row indicate significantly different means according to LSD post-hoc test $(p<0.05)$ (** $p<0.01 ;{ }^{* * *} p<0.001 ;$ n.s. not significant).

\begin{tabular}{|c|c|c|c|c|}
\hline \multirow[t]{2}{*}{ Sensory Descriptor } & \multirow[t]{2}{*}{ F-Values } & \multicolumn{3}{|c|}{ Vintage } \\
\hline & & 2004 & 2005 & 2006 \\
\hline \multicolumn{5}{|l|}{ Appearance } \\
\hline Amber color & $78.98 * * *$ & $7.5^{\mathrm{c}}$ & $5.1^{\mathrm{a}}$ & $6.2^{b}$ \\
\hline \multicolumn{5}{|c|}{ ODOR (Orthonasal perception) } \\
\hline Solvent odor & $79.38^{* * *}$ & $5.2^{\mathrm{a}}$ & $6.3^{b}$ & $7.7^{\mathrm{c}}$ \\
\hline Honey odor & $386.70 * * *$ & $6.5^{c}$ & $2.4^{\mathrm{a}}$ & $3.6^{b}$ \\
\hline Caramel odor & $311.64^{* * *}$ & $5.7^{\mathrm{c}}$ & $4.1^{\mathrm{b}}$ & $3.2^{\mathrm{a}}$ \\
\hline Rum odor & $87.53^{* * *}$ & $4.5^{\mathrm{a}}$ & $6.1^{b}$ & $6.2^{b}$ \\
\hline Dried fruit (figs) odor & $62.47^{* * *}$ & $5.9^{b}$ & $4.5^{\mathrm{a}}$ & $4.3^{\mathrm{a}}$ \\
\hline Baked fruit (apple) odor & $61.06^{* * *}$ & $2.8^{\mathrm{a}}$ & $4.2^{b}$ & $2.9^{\mathrm{a}}$ \\
\hline $\begin{array}{l}\text { Nutty odor } \\
\text { TASTE }\end{array}$ & $90.25^{* * *}$ & $5.6^{\mathrm{c}}$ & $4.7^{\mathrm{b}}$ & $3.8^{\mathrm{a}}$ \\
\hline Sweet taste & $10.61^{* *}$ & $5.3^{\mathrm{a}}$ & $5.6^{\mathrm{b}}$ & $5.9^{b}$ \\
\hline Sour taste & $46.07^{* * *}$ & $5.3^{b}$ & $4.5^{\mathrm{a}}$ & $4.3^{\mathrm{a}}$ \\
\hline \multicolumn{5}{|c|}{ FLAVOR (Retronasal perception) } \\
\hline Solvent flavor & $21.44^{* * *}$ & $2.0^{\mathrm{a}}$ & $2.4^{\mathrm{b}}$ & $2.7^{\mathrm{c}}$ \\
\hline Honey flavor & $22.20 * * *$ & $6.4^{\mathrm{b}}$ & $5.4^{\mathrm{a}}$ & $6.1^{b}$ \\
\hline Caramel flavor & $11.26^{* * *}$ & $5.3^{b}$ & $5.2^{b}$ & $4.7^{\mathrm{a}}$ \\
\hline Rum flavor & $51.44 * * *$ & $4.7^{\mathrm{a}}$ & $6.3^{c}$ & $5.6^{b}$ \\
\hline Dried fruit (figs) flavor & $19.73^{* * *}$ & $6.4^{\mathrm{b}}$ & $5.6^{\mathrm{a}}$ & $5.5^{\mathrm{a}}$ \\
\hline Baked fruit (apple) flavor & $92.55^{* * *}$ & $3.9^{\mathrm{a}}$ & $3.4^{\mathrm{a}}$ & $4.6^{b}$ \\
\hline Nutty flavor & 1.80 n.s. & 3.9 & 3.9 & 3.7 \\
\hline \multicolumn{5}{|l|}{ MOUTHFEEL } \\
\hline \multicolumn{5}{|l|}{ SENSATIONS } \\
\hline Body & $58.46^{* * *}$ & $6.9^{b}$ & $5.7^{\mathrm{a}}$ & $5.7^{\mathrm{a}}$ \\
\hline Alcohol & $22.04^{* * *}$ & $5.8^{b}$ & $5.1^{\mathrm{a}}$ & $5.2^{\mathrm{a}}$ \\
\hline
\end{tabular}

In general, the Vin Santo wines analyzed in the present study were highly aromatic, with 14 olfactory descriptors detected by the trained panel. Accordingly, in a study by Mazzaglia et al. [48], Malvasia wines from different Mediterranean areas were evaluated for their sensory properties, and in agreement with the present study, found a very complex sensory profile characterized by 21 sensory descriptors of which 17 related to olfactory terms. The samples evaluated in the present study, had a high sweet taste intensity and were full-bodied but, differently from traditional Vin Santo wines, they were not as much as high in alcohol perception. The total acidity was not negligible, sour perception by the sensory panel was reduced, probably due to the high intensity of sweet taste, which is known to modulate the perception of acid compounds [49]. Differently from previous studies [1,2,48], Colli Piacentini DOC Vin Santo wines were not perceived as astringent. This might be due to the high intensity of sweet taste and body that can modulate the perception of bitter and astringent compounds, respectively [50,51]. Vintage 2004 was also perceived as darker than the other wines. It is well known that during maturation, oxygen promotes deep changes in the phenolic compounds. In particular, polyphenol oxidation determines the production of quinone, and their polymerization results in yellow-brown compounds responsible for wine browning reactions as aging 
proceeds [52-54]. As a consequence, Vin Santo can be characterized by a natural color that ranges from golden straw to intense amber [1].

Partial least square (PLS) regression and variable importance in the projection (VIP) were used to study the relationship between sensory data and GC-FID data, and to establish which volatile compound could predict a specific orthonasal and/or retronasal odor perceived by the trained panel of assessors.

The positioning of the Vin Santo vintages in the two replicates is reported in the Scores plot (Figure 1a), whereas the relation between sensory data (red font) and volatile compounds (blue font) is reported in the Loadings plot (Figure 1b).

a

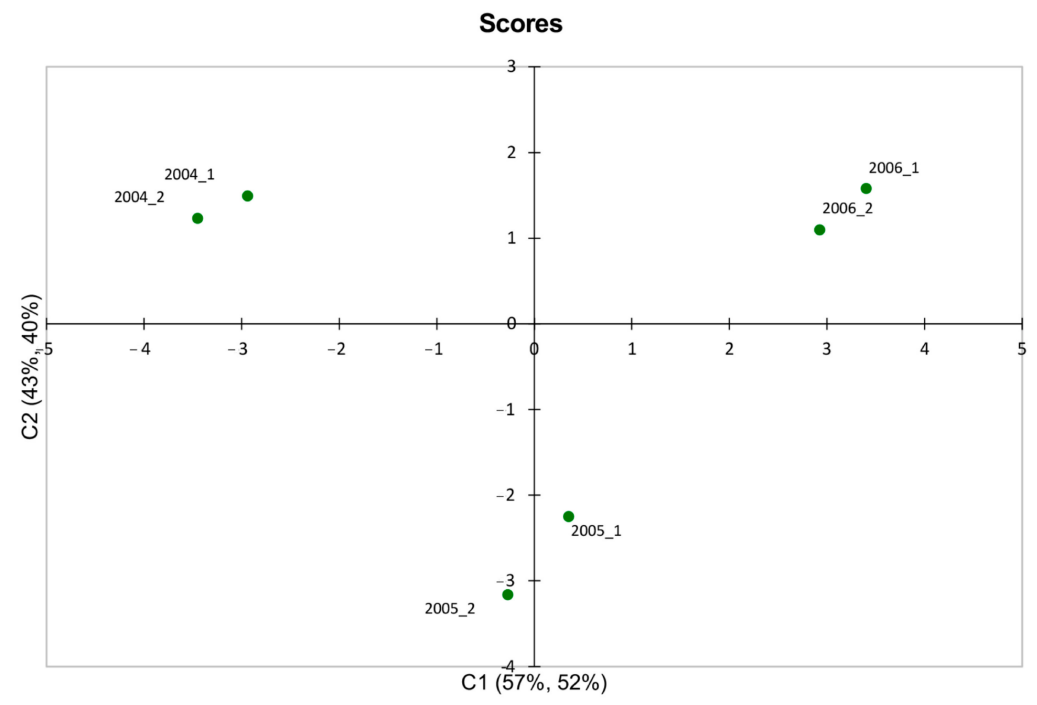

b

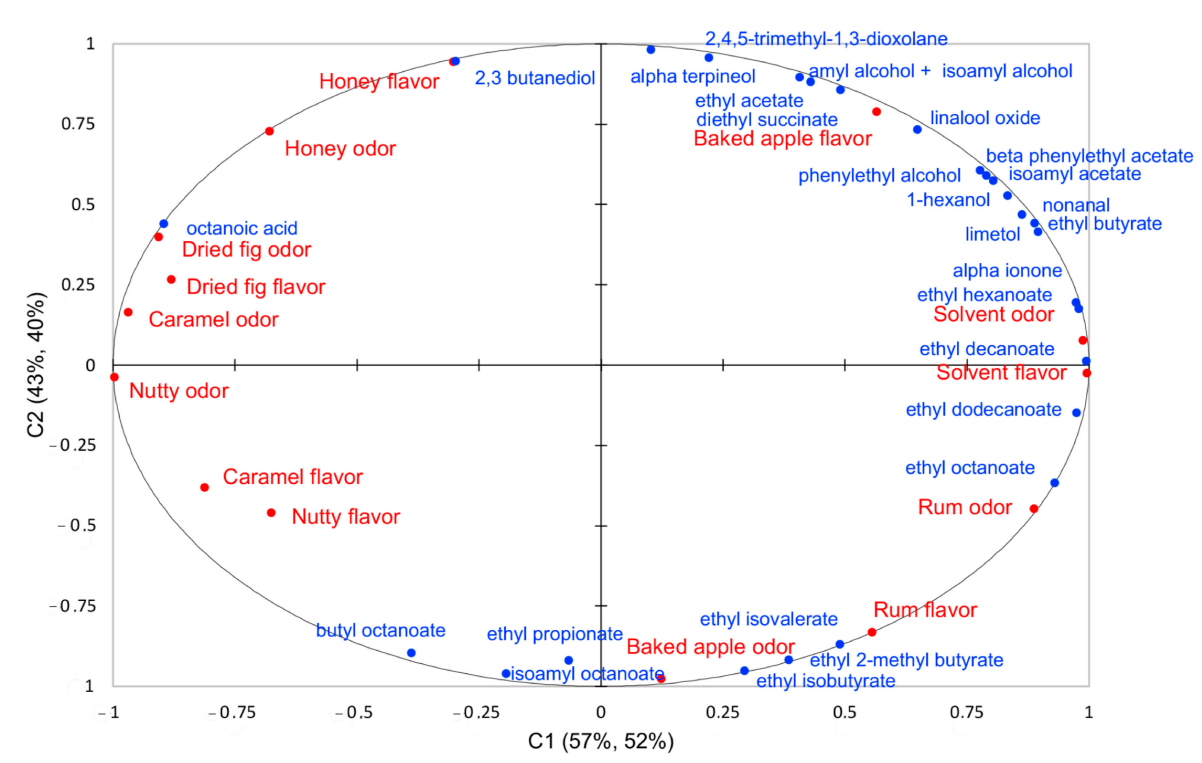

Figure 1. Scores (a) and Loadings (b) plots obtained by PLS modeling carried out on Vin Santo sensory aroma profile data $(\mathrm{Y})$ and volatile compounds data by GC-FID $(\mathrm{X})$. C1: first factor; $\mathrm{C}$ : second factor. 
The first factor (C1) explains, respectively, the $57 \%$ and $52 \%$ of the variation in $\mathrm{Y}$, while the second factor (C2) accounts for, respectively, the $43 \%$ and $40 \%$. The cumulative $\mathrm{Q}^{2}$ of the model was $0.95 \%$, reflecting an excellent relationship between the sensory and GC-FID data, while the cumulated $R^{2} Y$ and $\mathrm{R}^{2} \mathrm{X}$ cum corresponding to the correlations between the explanatory $(\mathrm{X})$ and dependent $(\mathrm{Y})$ variables with the components are very close to $1\left(R^{2} Y=0.97\right.$ and $R^{2} X=0.94$, respectively).

The first factor clearly differentiated the 2004 vintage (on the upper left pane) from the 2006 vintage (on the upper right pane), whereas the second factor differentiated vintage 2005 (on the lower panes) from the other wines (Figure 1a). Looking at Figure 1b, it is possible to gain information about the fingerprint of these three vintages. Vintage 2004 was mainly correlated to the sensory attributes honey, dried fig, caramel, and nutty odors and flavors, which are usually associated with oxidation notes [55]. These aroma sensory descriptors were related to octanoic acid and 2,3 butanediol, which have been reported to be responsible for sweetie and fatty notes [56]. On the contrary, vintage 2004 had the lowest perceived intensity of solvent and rum odors and flavors, which were the main descriptors characterizing vintages 2006 and 2005, respectively. These sensory descriptors were associated with volatile compounds, such as ethyl dodecanoate, and ethyl and isoamyl octanoate-responsible for alcoholic (cognac/brandy) notes-as well as ethyl proprionate and ethyl isobutyrate-responsible for ethereal, alcoholic, fusel, and pungent notes [55]. Vintages 2005 and 2006 were also described by the sensory descriptors baked apple odor (2005) and flavor (2006). Coherently, these vintages were also associated with higher concentrations of ethyl isovalerate and ethyl hexanoate (apple odor), as well as isoamyl acetate and diethyl succinate (apple flavor), which have been reported to be responsible for the perception of a fruity-apple odor [43,54,56-58].

On the basis of the data obtained by PLS modeling, variable importance in projection (VIP) was used to extract the most relevant volatile compounds for each sensory attribute (See supplementary Table S1). VIP results from a weighted sum of squares of the PLS-loadings, and it is related to the amount of explained Y-variable in each dimension. Figure 2 reported the VIP indices associated with a PLS model comprised of the first two components, allowing the identification of the explanatory variables that contribute the most to the model. The analysis showed that the baked apple odor, honey flavor, and odor, and rum flavor have low VIP indices (smaller than 0.8) on C1 (Figure 2a). Nevertheless, looking at the VIP indices on the second component all the variables show a great influence (Figure 2b).
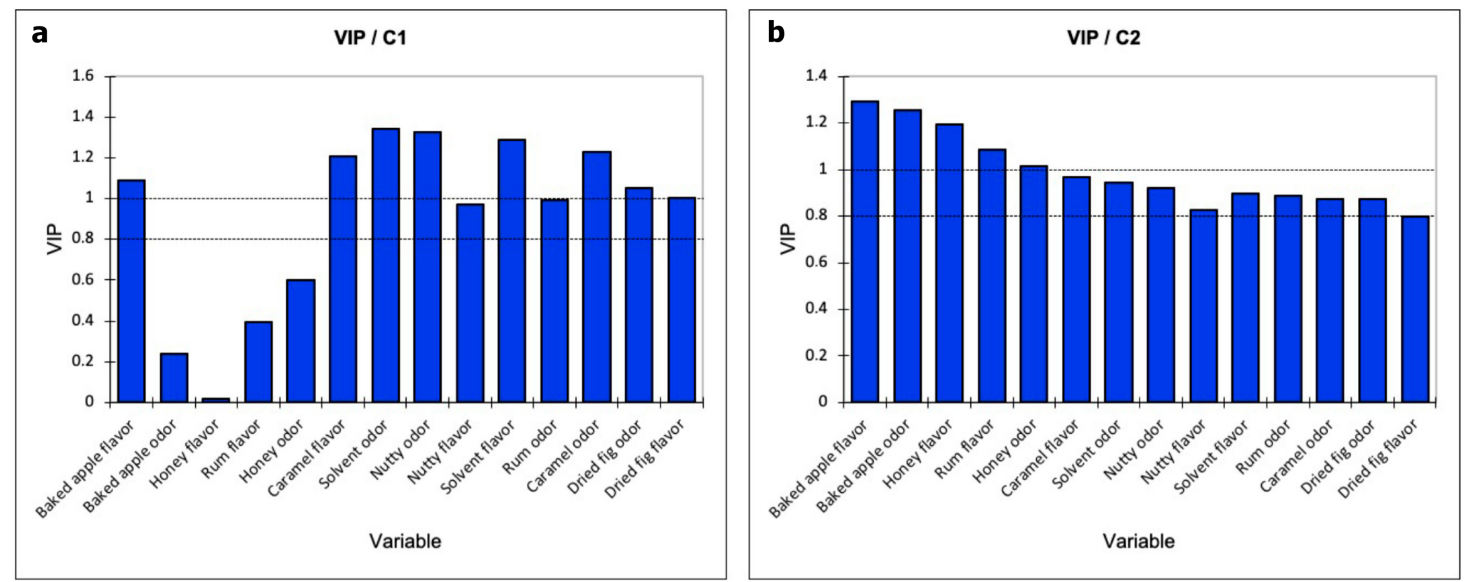

Figure 2. Variable importance in projection (VIP) values for the partial least squares analysis. (a) VIP indices on $\mathrm{C} 1$; (b) VIP indices on $\mathrm{C} 2$.

All together, these results allow the definition of the sensory characteristics of Vin Santo wine aged up to 15 years and consider for the first time the opportunity of pushing so far the aging process in Vin Santo from Malvasia di Candia grapes. Nor off-odors neither off-flavors have been identified in the samples, suggesting that the 15-year aging limit can still be considered acceptable for the 
quality of wines. However, further studies, are needed to investigate this aspect, especially taking into consideration the consumers' point of view regarding sensory acceptability.

\section{Conclusions}

In the present work, the characterization of volatile compounds and sensory attributes of long-term aging Vin Santo wine obtained from Malvasia di Candia aromatica were evaluated for the first time. Volatile compounds were identified by GC-MS on alcoholic extracts of wines, and a semi-quantitative analysis was carried out by GC. It was possible to identify 27 compounds belonging to 12 groups of volatiles, and a sufficient measure of priority was identified among the molecules responsible for the aroma.

From a sensory point of view, the Vin Santo wine analyzed presented a very complex sensory profile characterized by 19 sensory descriptors of which 14 related to olfactory terms, especially characterized by sweetie and fatty notes, solvent and rum odors and flavors, as well as apple odor and flavor. The relationship between sensory and analytical data investigated by means of the PLS modeling showed that specific volatile compounds could predict a specific orthonasal and/ or retro nasal odor perceived by the trained panel of assessors.

The combined approach can be useful to producers to characterize the sensory quality of wines during aging to define the most acceptable aging limit, given that the development of the aroma was also evident within three years. Finally, it is important to note that, in the present work, due to the selection of a limited number of vintages of only one producer, the generalization of the results was not possible. Therefore, future studies should consider different vintages, including younger ones, to define the evolution of aromatic profile over time.

Supplementary Materials: The following are available online at http://www.mdpi.com/2304-8158/9/12/1736/s1, Table S1: VIP coefficients of the models corresponding to each dependent variable.

Author Contributions: Conceptualization, M.L. and F.T.; Formal analysis, M.L., C.C., F.T. and M.B.; Funding acquisition, M.L.; Investigation, M.L., C.C., F.T. and M.B.; Methodology, M.L., F.T. and M.B.; Project administration, M.L.; Resources, M.L., C.C., F.T. and M.B.; Supervision, M.L. and M.B.; Visualization, M.L. and C.C.; Writing-original draft, M.L., C.C., F.T. and M.B.; Writing-review \& editing, M.L., C.C., F.T. and M.B. All authors have read and agreed to the published version of the manuscript.

Funding: This research received no external funding.

Acknowledgments: The authors thanks E. Bonomelli and the F. Terzi for technical collaboration.

Conflicts of Interest: The authors declare no conflict of interest.

\section{References}

1. Domizio, P.; Lencioni, L. Vin santo. In Advances in Food and Nutrition Research; Jackson, R.S., Ed.; Academic Press: Waltham, MA, USA, 2011; Volume 63, pp. 41-100.

2. Domizio, P.; Lencioni, L.; Ciani, M.; Di Blasi, S.; Pontremolesi, C.D.; Sabatelli, M.P. Spontaneous and inoculated yeast populations dynamics and their effect on organoleptic characters of Vinsanto wine under different process conditions. Int. J. Food Microbiol. 2007, 115, 281-289. [CrossRef] [PubMed]

3. European Commission. Commission Regulation (EU) No 401/2010 of 7 May 2010 amending and correcting Regulation (EC) No 607/2009 laying down certain detailed rules for the implementation of Council Regulation (EC) No 479/2008 as regards protected designations of origin and geographical indications, traditional terms, labelling and presentation of certain wine sector products. Off. J. Eur. Union 2010, 53, 13-59.

4. Domizio, P.; Manazzu, I.; Ciani, M. Impact of mother sediment on yeast growth, biodiversity, and ethanol production during fermentation of Vinsanto wine. Int. J. Food Microbiol. 2009, 129, 83-87. [CrossRef] [PubMed]

5. Erten, H. Relations between elevated temperatures and fermentation behaviour of Kloeckera apiculata and Saccharomyces cerevisiae associated with winemaking in mixed cultures. World J. Microbiol. Biotechnol. 2002, 18, 373-379. [CrossRef]

6. Fleet, G.H. Yeast interactions and wine flavour. Int. J. Food Microbiol. 2003, 86, 11-22. [CrossRef] 
7. Stella, C.; Aiello, C.; Sabatelli, M.P. Vinsanto toscano: Ricerche per una sua caratterizzazione. Agric. Ricerca. 1998, 173, 81-86.

8. Bucelli, P.; Piracci, A.; Giannetti, F.; Faviere, V. Il Vin Santo in Toscana. Composizione e Caratteri Sensoriali; Agenzia Regionale Toscana per lo Sviluppo e l'Innovazione nel Settore Agro-Forestale: Florence, Italy, 1998.

9. Borsa, D.; Carniel, D.; Asproudi, A.; Monticelli, L.; Crespan, M.; Costacurta, A. Caratterizzazione di uve Malvasia attraverso lo studio dei metaboliti secondari. Riv. Vitic. Enol. 2005, 58, 167-182.

10. Scienza, A. Atlante dei vini passiti italiani; Gribaudo, E., Ed.; Gruppo Feltrinelli: Milan, Italy, 2006.

11. Romani, C.; Lencioni, L.; Domizio, P. Chemical composition and organoleptic characteristics of Vinsanto wine obtained by using different Saccharomyces strains. Ann. Microbiol. 2009, 59, 76.

12. Ribéreau-Gayon, P.; Glories, Y.; Maujean, A.; Dubourdieu, D. The chemistry of Wine-Stabilization and Treatments. In Handbook of Enology, 2nd ed.; Wiley \& Sons, Ltd.: Chichester, UK, 2000; Volume 2.

13. Cassino, C.; Tsolakis, C.; Bonello, F.; Gianotti, V.; Osella, D. Wine evolution during bottle aging, studied by 1H NMR spectroscopy and multivariate statistical analysis. Food Res. Int. 2019, 116, 566-577. [CrossRef]

14. Picard, M.; Tempere, S.; de Revel, G.; Marchand, S. A sensory study of the ageing bouquet of red Bordeaux wines: A three-step approach for exploring a complex olfactory concept. Food Qual. Prefer. 2015, 42, 110-122. [CrossRef]

15. Robinson, A.L.; Boss, P.K.; Solomon, P.S.; Trengove, R.D.; Heymann, H.; Ebeler, S.E. Origins of grape and wine aroma. Part 1. Chemical components and viticultural impacts. J. Enol. Vitic. 2014, 65, 1-24. [CrossRef]

16. Styger, G.; Prior, B.; Bauer, F.F. Wine flavor and aroma. J. Ind. Microbiol. Biotechnol. 2011, 38, 1145-1159. [CrossRef] [PubMed]

17. Villamor, R.R.; Ross, C.F. Wine matrix compounds affect perception of wine aromas. Annu. Rev. Food Sci. Technol. 2013, 4, 1-20. [CrossRef] [PubMed]

18. Baiano, A.; Mentana, A.; Quinto, M.; Centonze, D.; Longobardi, F.; Ventrella, A.; Agostiano, A.; Varva, G.; De Gianni, A.; Terracone, C.; et al. The effect of in-amphorae aging on oenological parameters, phenolic profile and volatile composition of Minutolo white wine. Food Res. Int. 2015, 74, 294-305. [CrossRef] [PubMed]

19. Baiano, A.; Mentana, A.; Varva, G.; Quinto, M. Effects of different vinification procedures and aging containers on phenolic and volatile composition of Greco white wines. Eur. Food Res. Technol. 2017, 243, 1667-1680. [CrossRef]

20. Coetzee, C.; Du Toit, W.J. Sauvignon blanc wine: Contribution of ageing and oxygen on aromatic and non-aromatic compounds and sensory composition-A review. S. Afr. J. Enol. Vitic. 2015, 36, 347-365. [CrossRef]

21. Cutzach, I.; Chatonnet, P.; Dubourdieu, D. Study of the formation mechanisms of some volatile compounds during the aging of sweet fortified wines. J. Agric. Food Chem. 1999, 47, 2837-2846. [CrossRef]

22. Ferreira-Lima, N.E.; Burin, V.M.; Bordignon-Luiz, M.T. Characterization of Goethe white wines: Influence of different storage conditions on the wine evolution during bottle aging. Eur. Food Res. Technol. 2013, 237, 509-520. [CrossRef]

23. Hopfer, H.; Ebeler, S.E.; Heymann, H. The combined effects of storage temperature and packaging type on the sensory and chemical properties of Chardonnay. J. Agric. Food Chem. 2012, 60, 10743-10754. [CrossRef]

24. Ling, M.-Q.; Xie, H.; Hua, Y.-B.; Cai, J.; Li, S.-Y.; Lan, Y.-B.; Li, R.-N.; Duan, C.-Q.; Shi, Y. Flavor Profile Evolution of Bottle Aged Rosé and White Wines Sealed with Different Closures. Molecules 2019, $24,836$. [CrossRef]

25. Makhotkina, O.; Pineau, B.; Kilmartin, P.A. Effect of storage temperature on the chemical composition and sensory profile of Sauvignon Blanc wines: Effect of storage temperature on Sauvignon Blanc. Aust. J. Grape Wine Res. 2012, 18, 91-99. [CrossRef]

26. Ortega, A.F.; Lopez-Toledano, A.; Mayen, M.; Merida, J.; Medina, M. Changes in color and phenolic compounds during oxidative aging of sherry white wine. J. Food Sci. 2003, 68, 2461-2468. [CrossRef]

27. Ricci, A.; Parpinello, G.P.; Versari, A. Modelling the evolution of oxidative browning during storage of white wines: Effects of packaging and closures. Int. J. Food Sci. Tech. 2017, 52, 472-479. [CrossRef]

28. Silva Ferreira, A.C.; Hogg, T.; Guedes de Pinho, P. Identification of key odorants related to the typical aroma of oxidation-spoiled white wines. J. Agric. Food Chem. 2003, 51, 1377-1381. [CrossRef] [PubMed]

29. UNI EN ISO 13299. Analisi Sensoriale-Metodologia-Guida Generale per la Definizione del Profilo Sensoriale; International Organization for Standardization: Geneva, Switzerland, 2016. 
30. ISO 8586. Sensory Analysis - General Guidelines for the Selection, Training and Monitoring of Selected Assessors and Expert Sensory Assessors; International Organization for Standardization: Geneva, Switzerland, 2012.

31. ISO 8589. Sensory Analysis_-General Guidance for the Design of Test Rooms; International Organization for Standardization: Geneva, Switzerland, 2007.

32. ISO 3591. Sensory Analysis_-Apparatus_Wine-Tasting Glass; International Organization for Standardization: Geneva, Switzerland, 1997.

33. MacFie, H.J.H.; Bratchell, N.; Greenhoff, K.; Vallis, L.V. Designs to balance the effect of order of presentation and first order carry-over effects in hall tests. J. Sens. Stud. 1989, 4, 129-148. [CrossRef]

34. Wold, S.; Sjöström, M.; Eriksson, L. PLS-regression: A basic tool of chemometrics. Chemom. Intell. Lab. Syst. 2001, 58, 109-130. [CrossRef]

35. Martens, H.; Martens, M. Modified Jack-knife estimation of parameter uncertainty in bilinear modelling by partial least squares regression (PLSR). Food Qual. Prefer. 2000, 11, 5-16. [CrossRef]

36. Tenenhaus, M.; Pages, J.; Ambroisine, L.; Guinot, C. PLS methodology to study relationships between hedonic judgements and product characteristics. Food Qual. Prefer. 2005, 16, 315-325. [CrossRef]

37. Vasile Simone, G.; Montevecchi, G.; Masino, F.; Imazio, S.A.; Bignami, C.; Antonelli, A. Aromatic characterisation of Malvasia odorosissima grapevines and comparison with Malvasia di Candia aromatica. S. Afr. J. Enol. Vitic. 2018, 39, 77-88.

38. Masino, F.; Antonelli, A.; Vasile Simone, G.; Montevecchi, G.; Durán-Guerrero, E.; García-Barroso, C.; Bignami, C. Study of Aroma Profile in Malvasia di Candia Aromatica. In Proceedings of the IX symposium In Vino Analytica Scientia (IX IVAS), Trento, Italy, 14-17 July 2015.

39. Stevens, K.L.; Bomben, J.; Lee, A.; McFadden, W.H. Volatiles from grapes. Muscat of Alexandria. J. Agric. Food Chem. 1966, 14, 249-252. [CrossRef]

40. Gunata, Y.Z.; Bayonove, C.L.; Baumes, R.L.; Cordonnier, R.E. The aroma of grapes I. Extraction and determination of free and glycosidically bound fractions of some grape aroma components. J. Chromatogr. 1985, 331, 83-90. [CrossRef]

41. Mateo, J.; Jiménez, M. Monoterpenes in grape juice and wines. J. Chromatogr. 2000, 881, 557-567. [CrossRef]

42. D'Onofrio, C.; Matarese, F.; Cuzzola, A. Study of the terpene profile at harvest and during berry development of Vitis vinifera L. aromatic varieties Aleatico, Brachetto, Malvasia di Candia aromatica and Moscato bianco. J. Sci. Food Agric. 2016, 97, 2898-2907. [CrossRef]

43. Montevecchi, G.; Masino, F.; Vasile Simone, G.; Cerretti, E.; Antonelli, A. Aromatic profile of white sweet semi-sparkling wine from Malvasia di Candia aromatica grapes. S. Afr. J. Enol. Vitic. 2015, 36, 267-276. [CrossRef]

44. Gómez-Plaza, E.; Gil-Muñoz, R.; Carreño-Espín, J.; Fernández-López, J.A.; Martínez-Cutillas, A. Investigation on the aroma of wines from seven clones of Monastrell grapes. Eur. Food Res. Technol. 1999, 209, 257-260. [CrossRef]

45. Masino, F.; Montevecchi, G.; Arfelli, G.; Antonelli, A. Evaluation of the combined effects of enzymatic treatment and aging on lees on the aroma of wine from Bombino bianco grapes. J. Agric. Food Chem. 2008, 56, 9495-9501. [CrossRef]

46. Shinohara, T. Gas chromatographic analysis of volatile fatty acids in wines. Agric. Biol. Chem. 1985, $49,2211-2212$.

47. Liberatore, M.T.; Pati, S.; Del Nobile, M.A.; La Notte, E. Aroma quality improvement of Chardonnay white wine by fermentation and ageing in barrique on lees. Food Res. Int. 2010, 43, 996-1002. [CrossRef]

48. Mazzaglia, A.; Lanza, C.M. Physicochemical and Sensory Characterization of Malvasia Wines from Different Mediterranean Areas. J. Food Qual. 2018, 2018, 2398149. [CrossRef]

49. Jackson, R.S. Wine Science: Principle, Practice, Perception; Academic Press: San Diego, CA, USA, $2000 ;$ p. 645.

50. Small, D.M.; Prescott, J. Odor/taste integration and the perception of flavor. Exp. Brain Res. 2005, 166, 345-357. [CrossRef]

51. Sáenz-Navajas, M.P.; Campo, E.; Fernández-Zurbano, P.; Valentin, D.; Ferreira, V. An assessment of the effects of wine volatiles on the perception of taste and astringency in wine. Food Chem. 2010, 121, 1139-1149. [CrossRef]

52. Singleton, V.L. Oxygen with phenols and related reactions in must, wines, and model system: Observations and practical implications. Am. J. Enol. Vitic. 1987, 38, 69-77.

53. Li, H.; Guo, A.; Wang, H. Mechanisms of oxidative browning of wine. Food Chem. 2008, 108, 1-13. [CrossRef] 
54. Del Caro, A.; Piombino, P.; Genovese, A.; Moio, L.; Fanara, C.; Piga, A. Effect of bottle storage on colour, phenolics and volatile composition of Malvasia and Moscato white wines. S. Afr. J. Enol. Vitic. 2014, 35, 128-138. [CrossRef]

55. Francisco, J.; Narváez-Zapata, J.A.; Larralde-Corona, C.P. Microbial diversity and flavor quality of fermented beverages. In Microbial Production of Food Ingredients and Additives; Academic Press: Waltham, MA, USA, 2017; pp. 125-154.

56. Muratore, G.; Asmundo, C.N.; Lanza, C.M.; Caggia, C.; Licciardello, F.; Restuccia, C. Influence of Saccharomyces uvarum on volatile acidity, aromatic and sensory profile of Malvasia delle Lipari wine. Food Technol. Biotechnol. 2007, 45, 101-106.

57. Nicolini, G.; Moser, S.; Larcher, R.; Versini, G.; Fedrizzi, B. Technological characterization of Malvasia colli di Parma doc juice and wine. In Proceedings of the Malvasias: III International Symposium, La Palma, Canary Islands, Spain, 23-27 May 2009; p. 10.

58. Del Caro, A.; Fanara, C.; Genovese, A.; Moio, L.; Piga, A.; Piombino, P. Free and enzymatically hydrolysed volatile compounds of sweet wines from Malvasia and Muscat grapes (Vitis vinifera L.) grown in Sardinia. S. Afr. J. Enol. Vitic. 2012, 33, 115-121. [CrossRef]

Publisher's Note: MDPI stays neutral with regard to jurisdictional claims in published maps and institutional affiliations.

(C) 2020 by the authors. Licensee MDPI, Basel, Switzerland. This article is an open access article distributed under the terms and conditions of the Creative Commons Attribution (CC BY) license (http://creativecommons.org/licenses/by/4.0/). 